\title{
PERSEPSI KOMUNIKASI VISUAL TERHADAP MEDIA PROMOSI BRT (BUS RAPID TRANSIT) TRANS JATENG KORIDOR PURWOKERTO-PURBALINGGA
}

\author{
Fauzan Romadlon ${ }^{1}$ \\ Pungky Febi Arifianto ${ }^{2}$ \\ Nofrizaldi $^{3}$
}

Diterima April. 13, 2021; Disetujui Mei. 14, 2021.

\begin{abstract}
Abstrak: Moda transportasi BRT (Bus Rapid Transit) koridor Purwokerto-Purbalingga memiliki elemen komunikasi visual berupa Transit ads sebagai media promosi wisata kedua daerah. Penelitian ini bertujuan sebagai kajian persepsi masyarakat dalam melihat efektivitas komunikasi visual dalam media promosi tersebut. Penelitian ini menggunakan skala likert dalam penilaian serta ANOVA dalam menganalisis hasilnya. Hasil studi menunjukkan bahwa kriteria persepsi didasari oleh faktor demografis terutama jenis kelamin dan tipe pekerjaan. Laki-laki dan perempuan mempunyai perspektif yang berbeda terkait desain komunikasi visual yang diterapkan di badan BRT. Penelitian ini juga memberikan gambaran bahwa promosi yang diharapkan oleh masyarakat umumnya semakin beragam. Promosi diharapkan tidak sebatas promosi wisata, dimungkinkan juga promosi kuliner, promosi batik, dan ajakan menggunakan transportasi umum hingga kampanye pencegahan perilaku korupsi.
\end{abstract}

Kata Kunci: persepsi; media promosi; komunikasi visual; bus rapid transit; Purwokerto-Purbalingga

Abstract: Bus Rapid Transit (BRT) is one of public transportation modes in Purwokerto-Purbalingga that has a visual communication element as form as transit ads for a tourism promotion media. This study aims to analyze public perceptions in terms of the effectiveness of visual communication of the promotional media. This study uses a Likert scale to assess and ANOVA to analyze the results. The results of the study indicate that the perception criteria are based on demographic factors, especially gender and job

${ }^{1}$ Fauzan Romadlon adalah staf pengajar pada Program Studi Teknik Industri, Fakultas Rekayasa Industri dan Desain, Institut Teknologi Telkom Purwokerto.

${ }^{2}$ Pungky Febi Arifianto adalah staf pengajar pada Program Studi Manajemen, STIE Perbanas Surabaya.

${ }^{3}$ Nofrizaldi adalah staf pengajar pada Program Studi Desain Komunikasi Visual, Fakultas Rekayasa Industri dan Desain, Institut Teknologi Telkom Purwokerto. e-mail :fauzan@ittelkom-pwt.ac.id

e-mail: pungky.arifianto@perbanas.ac.id

e-mail: nofrizaldi@ittelkom-pwt.ac.id 
type. Men and women have different perspectives regarding the visual communication design that is applied in BRT. This study also illustrates that the expected promotion of the community as general is increasingly diverse. Promotion is expected not to be limited to tourism promotion, it is also possible to promote culinary, batik promotion, and invitations to use public transportation to campaign to prevent corrupt behavior.

Keywords: perception; promotion media; visual communication; bus rapid transit; Purwokerto-Purbalingga

\section{Pendahuluan}

Komunikasi visual dapat diartikan sebagai sebuah tampilan yang memiliki visi dan misi yaitu dapat mewakili sebuah perancangan dalam sebuah komunikasi melalui gambar. Komunikasi visual bertujuan untuk penyampaian pesan secara visual dan/atau audio visual kepada audience (Tinarbuko \& Piliang, 2008). Selain itu, komunikasi visual merupakan suatu aktivitas yang memiliki tindakan dalam menghasilkan komunikasi secara visual kedalam sebuah media sehingga dapat digunakan sebagai sarana industri dan ditujukan untuk memberikan pesan khusus yang memiliki dampak atau perubahan pada masyarakat (Fiadcara, 2004).

Sebagai sarana komunikasi, komunikasi visual memiliki beberapa media baik yang statis maupun dinamis. Adapun media dalam bentuk statis namun memiliki sifat dinamis adalah Transit ads. Media tersebut umumnya berada pada badan sebuah kendaraan bergerak yang berpindah-pindah tempat. Sehingga penggunaan sarana promosi ini memiliki jangkauan audiens yang luas serta beragam meskipun juga memiliki kekurangan yakni waktu yang dibutuhkan audiens dalam menerima pesan relatif singkat (Nurhayati, 2018) $\square$.

Salah satu moda transportasi yang digunakan sebagai sarana promosi adalah Bus Rapid Transit (BRT) Trans Jateng dengan jurusan Purwokerto-Purbalingga.
BRT ini diinisiasi Kementrian Perhubungan Jawa Tengah. BRT Purwokerto-Purbalingga adalah salah satu moda transportasi baru di Kabupaten Banyumas dan Purbalingga yang diresmikan pada 13 Agustus 2018 dengan rute Terminal $\mathrm{Bu}-$ lupitu, Purwokerto hingga Terminal Bukateja, Purbalingga (Ridlo, 2018).

Sebagai informasi, pengoperasian BRT di Indonesia berawal dari Provinsi DKI Jakarta yang memulainya sejak tahun 2001, lalu diikuti kota-kota besar lain seperti Kota Palembang, Kota Yogyakarta, dan Kota Semarang (Dishubjabar, 2015). Banyaknya kota besar di Indonesia yang mulai menerapkan BRT mengindikasikan bahwa sistem transportasi BRT bisa dijadikan alternatif moda transportasi masyarakat. BRT memiliki keunggulan seperti dari segi keamanan, kenyamanan, mudah dijangkau bagi kaum urban, tepat waktu, serta waktu tempuh dan waktu tunggu yang lebih singkat dibandingkan bis konvensional (Afolabi, 2016) dan salah satu solusi untuk mencegah kemacetan sebuah kota (Cao, Cao, Zhang, \& Huang, 2015).

Pada penelitian ini, persepsi atau sudut pandang masyarakat menjadi faktor utama untuk mencetuskan sebuah kebijakan. Persepsi mempunyai tiga tahapan yaitu: seleksi, interpretasi, dan reaksi. Dapat dijelaskan seleksi adalah proses penyaringan dengan bantuan panca indera sedangkan interpretasi adalah proses mengorganisasikan sehingga 


\section{Fauzan Romadlon ${ }^{1}$ \\ Pungky Febi Arifianto ${ }^{2}$ \\ Nofrizaldi ${ }^{3}$}

mempunyai arti, sedangkan reaksi adalah terjemahan berupa tingkah laku manusia (Nurchotimah, 2018). Pada bidang transportasi, persepsi digunakan untuk mengukur efektifitas berkendara di jalan apabila menggunakan kendaraan pribadi maupun kendaraan umum (Meutia, Wibowo, \& Weningtyas, 2015).

Lebih lanjut lagi, persepsi merupakan proses seseorang menyeleksi, mengatur serta menginterpretasikan informasi - informasi yang masuk untuk menciptakan gambaran dari keseluruhan yang memiliki arti. Sebagai jenis produk jasa transportasi yang baru bagi masyarakat Purwokerto dan Purbalingga, pemerintah melakukan upaya kampanye sebagai media promosi khususnya wisata dengan memanfaatkan komunikasi visual di badan BRT. Promosi ini mempunyai arti sebagai sebuah interpretasi informasi untuk memunculkan sebuah gambaran dan mengajak konsumen untuk membeli atau menikmati suatu produk yang dijual dengan meyakinkan kemanfaatannya (Kotler \& Keller, 2012). Faktanya beberapa warga masih menganggap komunikasi visual tersebut masih belum efektif sehingga dibutuhkan sebuah kajian persepsi.

Berdasarkan hal tersebut, dibutuhkan sebuah kajian persepsi komunikasi visual di badan BRT yang dalam hal ini dipakai pemerintah dalam untuk menyampaikan sebuah pesan. Persepsi tersebut digunakan untuk mengukur dan menilai warga setempat terkait seberapa besar pengaruh efektivitas penggunaan media komunikasi visual pada promosi iklan di badan BRT. Ditambah lagi, penilaian ini digunakan untuk menentukan apakah promosi yang sudah dilakukan pemerintah melalui media tersebut telah efektif tersampaikan kepada masyarakat sekitar atau belum.

\section{Metode Penelitian}

Penelitian ini diawali dengan survei
Persepsi Komunikasi Visual Terhadap Media Promosi BRT (Bus Rapid Transit) Trans Jateng Koridor Purwokerto-Purbalingga

pendahuluan pada objek penelitian. Survei pendahuluan bertujuan untuk melihat dan mengamati komunikasi visual pada badan BRT Purwokerto-Purbalingga terkini (Gambar 1-3). Pengumpulan data dilakukan kepada para pengguna dan non pengguna BRT dengan mengambil sampel secara acak di Purwokerto dan Purbalingga sebanyak 108 responden.

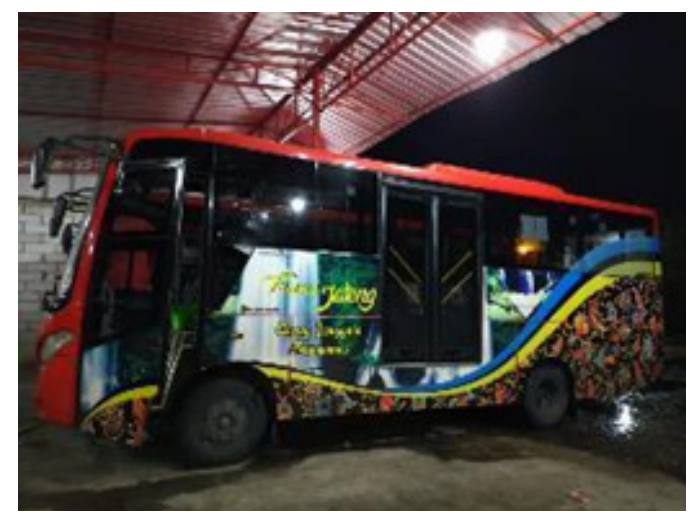

Gambar 1. Komunikasi visual BRT Purwokerto-Purbalingga

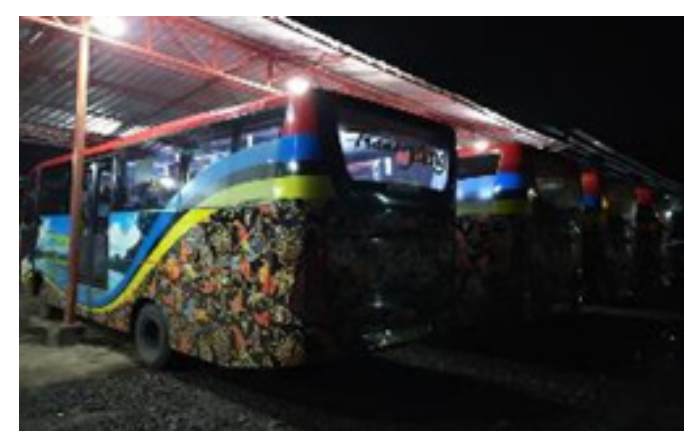

Gambar 2. BRT Purwokerto-Purbalingga tampak belakang

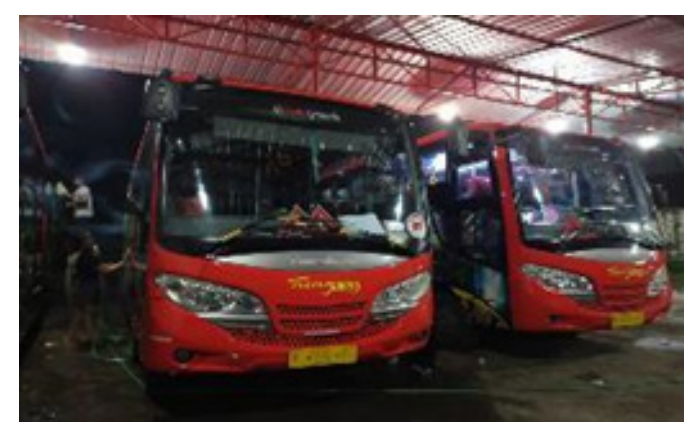

Gambar 3. BRT Purwokerto-Purbalingga tampak depan 
Data yang diambil adalah demografi pengguna yaitu jenis kelamin, pekerjaan, dan domisili. Data diambil menggunakan aplikasi google form. Selain itu, dalam melengkapi aspek persepsi, difokuskan pada elemen komunikasi visual BRT, promosi yang menarik perhatian, informasi tersampaikan dengan baik, gambar atau promosi pada badan BRT terlihat dengan jelas, tulisan dan warna promosi BRT terlihat dengan baik dan jelas serta apakah halte menyediakan informasi yang lengkap terkait BRT (Tabel 1).

Tabel 1. Kriteria penilaian persepsi komunikasi visual pada promosi di BRT

(Olahan Data)

\begin{tabular}{|c|l|}
\hline Kode & \multicolumn{1}{|c|}{ Kriteria } \\
\hline A1 & $\begin{array}{l}\text { BRT memiliki elemen komunikasi } \\
\text { visual }\end{array}$ \\
\hline A2 & $\begin{array}{l}\text { Promosi pada badan BRT menarik } \\
\text { perhatian }\end{array}$ \\
\hline A3 & $\begin{array}{l}\text { Informasi (komunikasi visual) } \\
\text { tersampaikan dengan baik }\end{array}$ \\
\hline A4 & $\begin{array}{l}\text { Gambar promosi pada badan BRT } \\
\text { terlihat dengan jelas }\end{array}$ \\
\hline A5 & $\begin{array}{l}\text { Tulisan Promosi pada badan BRT } \\
\text { terlihat dengan jelas }\end{array}$ \\
\hline A6 & $\begin{array}{l}\text { Warna Dominan pada BRT mudah } \\
\text { dikenali }\end{array}$ \\
\hline A7 & $\begin{array}{l}\text { Halte menyediakan informasi yang } \\
\text { cukup terkait BRT (contoh: rute, } \\
\text { jam kedatangan, fasilitas halte) }\end{array}$ \\
\hline
\end{tabular}

Penilaian tiap persepsi diukur menggunakan skala likert dengan angka satu merepresentasikan sangat tidak setuju, angka dua adalah tidak setuju, angka tiga normal atau moderate, angka empat (setuju) dan angka lima (sangat setuju). Setelah itu, data yang terkumpulkan dicari tingkat signifikansi korelasi antara demografis dengan persepsi masyarakat terkait komunikasi visual yang diterapkan pada promosi pada BRT dengan analisis statistika deskriptif dan ANOVA (analysis of variance) dengan menggunakan software Minitab 16 dengan alfa 5\%.

\section{Hasil dan Pembahasan}

\section{Tinjauan Elemen Komunikasi Visu- al}

Dalam transit ads yang ada pada badan bus BRT koridor Purwokerto Purbalingga memiliki elemen visual komunikasi visual. Elemen tersebut terdiri dari tipografi, simbolisme, ilustrasi dan fotografi (Gambar 4-7). Elemen tersebut digabungkan menjadi satu dengan kaidah desain komunikasi visual sehingga menghasilkan produk komunikasi visual. Pada elemen tipografi terdapat tulisan Trans Jateng yang menggunakan tipe huruf Script yang identik dengan tulisan tangan. Tipografi tersebut berwarna kuning dengan stroke berwarna hitam. Penggunaan warna kuning agar kontras dengan background yang didominasi oleh gambar lanskap ataupun warna dasar bus yang berwarna merah. Logo Jateng menjadi elemen simbolisme yang hadir dalam transit ads BRT tersebut. Hal ini dikarenakan bus ini dikelola oleh Dinas Perhubungan Provinsi Jawa Tengah di bawah kendali Pemerintah Provinsi Jawa Tengah.

Batik khas Banyumas menjadi elemen ilustrasi yang dijadikan sebuah penggambaran akan ciri khas Banyumas. Penggambaran elemen batik ini juga sebagai tanda bahwa motif tersebut merupakan simbolisasi akan sebuah kebanggaan corak Banyumas supaya lebih dikenal oleh khalayak umum. Sedangkan elemen fotografi menampilkan beberapa lanskap pemandangan wisata di wilayah Barlingmascakeb (Banjarnegara, Purbalingga, Banyumas, Cilacap dan Kebumen). Elemen fotografi tersebut mengindikasikan bahwa transit ads ini bertujuan untuk mengedukasi masyarakat untuk lebih mengenal objek wisata di tempat tersebut.

Objek wisata tersebut meliputi objek wisata Pantai Permisan Nusa Kambangan Cilacap, Kebun RayaBaturraden, Banyumas, dan Curug Jenggala Banyumas. Se- 
Fauzan Romadlon ${ }^{1}$

Pungky Febi Arifianto ${ }^{2}$

Nofrizaldi ${ }^{3}$

lain itu, beberapa objek wisata juga ditampilkan dalam bus ini akan tetapi tidak kami capture seperti Goa Lawa Purbalingga dan Wisata Air Owabong Purbalingga.

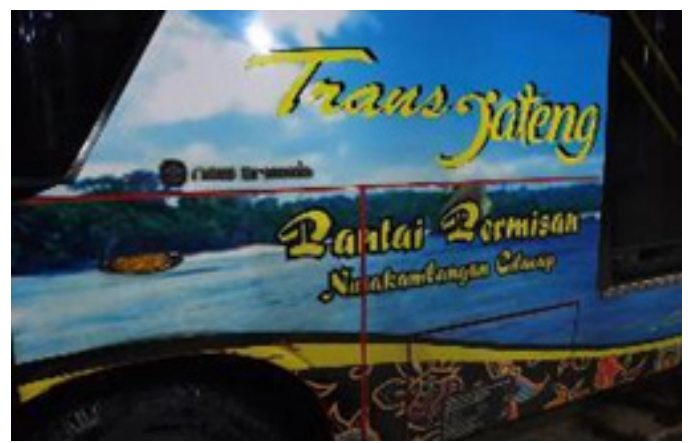

Gambar 4. Gambar promosi Pantai Permisan Nusakambangan Cilacap

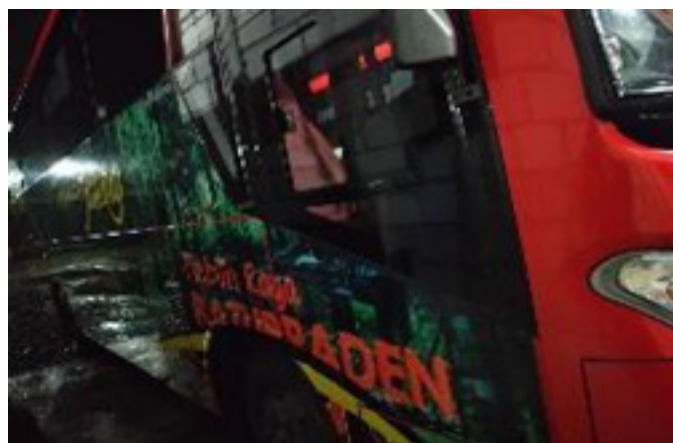

Gambar 5. Gambar Promosi Kebun raya Baturraden Purwokerto,Banyumas

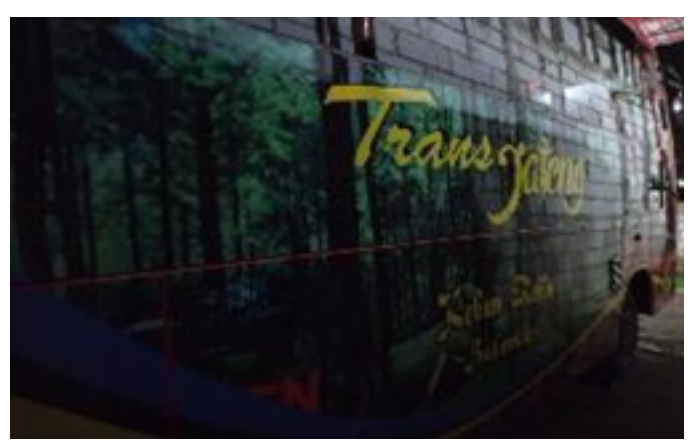

Gambar 6. Gambar Promosi Kebun raya Baturraden Purwokerto,Banyumas
Persepsi Komunikasi Visual Terhadap Media Promosi BRT (Bus Rapid Transit) Trans Jateng Koridor Purwoker-

to-Purbalingga

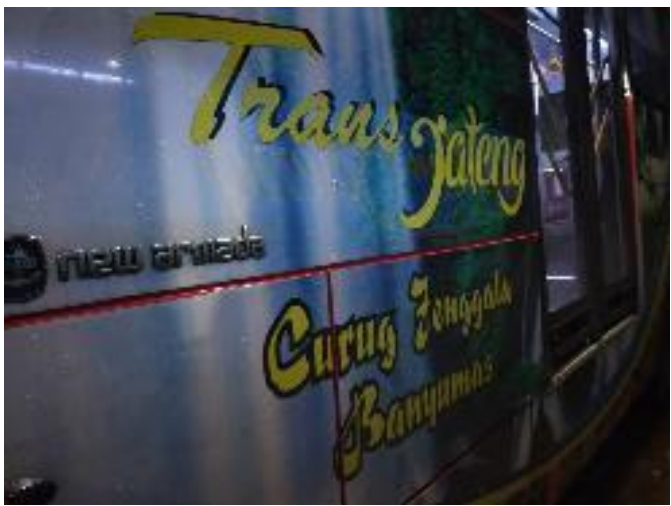

Gambar 7. Promosi Curug Jenggala Banyumas

\section{Demografi Responden}

Responden yang disurvei sebanyak 108 orang dengan domisili di Purwokerto, Purbalingga, dan sekitarnya seperti terlihat pada Tabel 2. Beberapa responden ada yang pernah menggunakan BRT dan beberapa belum pernah menggunakan BRT. Responden yang kami survei adalah responden yang memiliki pengalaman dalam melihat atau mengamati dari luar, meskipun belum pernah menggunakan BRT tersebut.

Berdasarkan Tabel 2, jumlah responden laki-laki mempunyai persentase

Tabel 2. Demografis responden (Olahan data)

\begin{tabular}{|l|l|r|}
\hline \multicolumn{2}{|l|}{ Variabel Pengguna } & Persentase \\
\hline $\begin{array}{l}\text { Jenis } \\
\text { kelamin }\end{array}$ & Laki-laki & 65.38 \\
\cline { 2 - 3 } & Perempuan & 34.62 \\
\hline Domisili & Purwokerto & 67.30 \\
\cline { 2 - 3 } & Purbalingga & 4.82 \\
\cline { 2 - 3 } & Banyumas & 12.50 \\
\cline { 2 - 3 } & Lainnya & 15.38 \\
\hline Pekerjaan & Pelajar & 55.77 \\
\cline { 2 - 3 } & Guru/dosen & 32.69 \\
\cline { 2 - 3 } & $\begin{array}{l}\text { Karyawan } \\
\text { swasta }\end{array}$ & 7.69 \\
\cline { 2 - 3 } & Lainnya & 3.84 \\
\hline
\end{tabular}


yang lebih banyak dibandingkan dengan persentase wanita yaitu pada kisaran 65\%. Selanjutnya, mayoritas responden berdomisili di wilayah Purwokerto sebesar 67.30\%, diikuti tempat di luar Purwokerto dan Purbalingga, Banyumas, dan Purbalingga. Selain itu, mayoritas responden adalah berprofesi sebagai pelajar, diikuti guru atau dosen, dan karyawan swasta.

\section{Analisis Statistika}

Perhitungan statistika yang digunakan adalah melalui perhitungan skala likert. Skala likert yang dipakai adalah kisaran satu hingga lima. Skala likert ini digunakan untuk mengukur persepsi komunikasi visual di BRT sebagai media promosi. Setelah data diolah, kemudian disusun interval respon dengan respon maksimal adalah $100 \%$ dan respon minimal adalah o\%. Respon tersebut kemudian dibagi kedalam lima kategori seperti pada Tabel 3. Lima kategori menunjukkan jumlah penilaian pada skala likert yang berjumlah lima. Pada Tabel 3 menunjukkan bahwa interval akumulasi atau perhitungan respon dari o\% hingga $19.99 \%$ mengindikasikan bahwa respon komunikasi visual pada BRT sebagai media promosi adalah sangat tidak setuju. Selanjutnya, persentase respon dari 20\% hingga 39,99\% adalah tidak setuju, 40\%-59,99\% adalah moderat atau normal, 60\%-79.99\% adalah setuju dan sisanya adalah sangat setuju.

Berdasarkan perhitungan skala likert (Tabel 4) ditunjukkan beberapa hasil respon masyarakat sebagai responden. Pada

Tabel 3. Persentase Nilai yang Dikonversi (Olahan data)

\begin{tabular}{|l|l|}
\hline \multicolumn{1}{|c|}{ Respon (\%) } & \multicolumn{1}{c|}{ Keterangan } \\
\hline o.00-19.99 & Sangat Tidak Setuju \\
\hline $20.00-39.99$ & Tidak Setuju \\
\hline $40.00-59.99$ & Moderat \\
\hline $60.00-79.99$ & Setuju \\
\hline $80.00-100.0$ & Sangat Setuju \\
\hline
\end{tabular}

kriteria pertama ditunjukkan bahwa respon masyarakat terhadap BRT memiliki elemen komunikasi visual (A1) sebesar $84 \%$. Hal ini menunjukkan tingkat respon masyarakat adalah sangat setuju. Selain

Tabel 4. Perhitungan skala likert.

\begin{tabular}{|c|c|c|c|}
\hline Kode & Kriteria & $\begin{array}{c}\text { Persentase } \\
(\%)\end{array}$ & Respon \\
\hline $\mathrm{A}_{1}$ & $\begin{array}{l}\text { BRT } \\
\text { memiliki } \\
\text { elemen } \\
\text { komunikas } \\
\text { i visual }\end{array}$ & 84 & $\begin{array}{l}\text { Sangat } \\
\text { setuju }\end{array}$ \\
\hline A2 & $\begin{array}{l}\text { Promosi } \\
\text { pada } \\
\text { badan BRT } \\
\text { menarik } \\
\text { perhatian }\end{array}$ & 71 & Setuju \\
\hline $\mathrm{A}_{3}$ & $\begin{array}{l}\text { Informasi } \\
\text { (komunika } \\
\text { si visual) } \\
\text { tersampaik } \\
\text { an dengan } \\
\text { baik }\end{array}$ & 68 & Setuju \\
\hline $\mathrm{A}_{4}$ & $\begin{array}{l}\text { Gambar } \\
\text { promosi } \\
\text { pada } \\
\text { badan BRT } \\
\text { terlihat } \\
\text { dengan } \\
\text { jelas }\end{array}$ & 72 & Setuju \\
\hline As & $\begin{array}{l}\text { Tulisan } \\
\text { Promosi } \\
\text { pada } \\
\text { badan BRT } \\
\text { terlihat } \\
\text { dengan } \\
\text { jelas }\end{array}$ & 66 & Setuju \\
\hline A6 & $\begin{array}{l}\text { Warna } \\
\text { Dominan } \\
\text { pada BRT } \\
\text { mudah } \\
\text { dikenali }\end{array}$ & 75 & Setuju \\
\hline A7 & $\begin{array}{l}\text { Halte } \\
\text { menyediak } \\
\text { an } \\
\text { informasi } \\
\text { yang cukup } \\
\text { terkait } \\
\text { BRT (ex. } \\
\text { Rute, jam } \\
\text { kedatanga } \\
\text { n, fasilitas } \\
\text { halte) }\end{array}$ & 63 & Setuju \\
\hline
\end{tabular}




\section{Fauzan Romadlon ${ }^{1}$ Pungky Febi Arifianto ${ }^{2}$ Nofrizaldi $^{3}$}

Persepsi Komunikasi Visual Terhadap

Media Promosi BRT (Bus Rapid Tran-

sit) Trans Jateng Koridor Purwoker-

to-Purbalingga itu, Respon masyarakat terkait proses promosi komunikasi visual pada badan BRT menarik perhatian (A2) ditunjukkan pada persentase yang lebih rendah dari A1 yaitu $71 \%$. Selanjutnya, pada respon informasi (komunikasi Visual) pada badan BRT tersampaikan dengan baik (A3) didapatkan akumulasi persentase sebesar 68\% dan respon terkait gambar promosi pada badan BRT terlihat dengan jelas (A4) memiliki akumulasi respon sebanyak $72 \%$. Lebih lanjut lagi, Tulisan promosi (A5) dan warna dominan pada badan BRT terlihat dengan jelas (A6) menghasilkan akumulasi persentase sebesar $66 \%$ dan $75 \%$. Terakhir terkait respon fungsionalitas halte pemberhentian BRT yang menyediakan informasi seperti rute, waktu kedatangan bus, fasilitas halte, dan fasilitas umum terdekat (A7) memiliki akumulasi persentase sebesar $63 \%$.

Hasil perhitungan statistika menggunakan ANOVA (Analysis of Variance) dapat dilihat pada Tabel 5. Perhitungan ANOVA digunakan untuk menentukan factor-faktor yang mempunyai korelasi yang signifikan pada respon terhadap komunikasi visual promosi di badan BRT dengan demografi responden. Korelasi yang signifikan ditunjukkan dengan nilai p-value di bawah 0.05. Berdasarkan perhitungan tersebut, hampir semua respon memiliki tingkat signifikansi dengan de-

Tabel 5. Perhitungan statistika

\begin{tabular}{|c|c|c|}
\hline $\begin{array}{c}\text { Perny } \\
\text { ataan }\end{array}$ & $\begin{array}{c}\text { Faktor } \\
\text { signifikansi }\end{array}$ & p-value \\
\hline A1 & - & - \\
\hline A2 & Jenis Kelamin & 0.015 \\
\hline A3 & Jenis Kelamin & 0.018 \\
\hline & Pekerjaan & 0.009 \\
\hline A4 & Pekerjaan & 0.009 \\
\hline A5 & Jenis Kelamin & 0.001 \\
\hline & Pekerjaan & 0.020 \\
\hline A6 & Jenis Kelamin & 0.004 \\
\hline A7 & Pekerjaan & 0.004 \\
\hline
\end{tabular}

mografi responden kecuali respon masyarakat terhadap BRT memiliki elemen komunikasi visual yang diterapkan di BRT (A1).

Lebih lanjut lagi, A2 dan A6 memiliki tingkat signifikansi dengan jenis kelamin respon dengan nilai masing-masing p-value adalah 0.015 dan 0.004. Hal tersebut menunjukkan bahwa perbedaan jenis kelamin mempengaruhi respon terhadap tingkat ketertarikan pada promosi di badan BRT (A2) dan dominasi warna pada badan BRT.Selain itu, pada respon yang lain, dimana A3, A4, dan A5 mempunyai tingkat signifikansi dengan jenis kelamin dan pekerjaan responden. Hal tersebut mengindikasikan bahwa informasi desain komunikasi visual dapat tersampaikan dengan baik kepada responden dan mereka memahami visualisasi sebagai proses promosi melalui visualisasi gambar pada badan BRT (A3), gambar promosi (A4) dan tulisan (A5) pada badan BRT terlihat dengan jelas mendapatkan respon yang beragam baik bagi responden laki-laki ataupun perempuan dan pekerjaan yang beragam baik sebagai siswa, guru/dosen, maupun karyawan swasta. Sedangkan pada respon terkait penyediaan informasi yang cukup di halte (A7) menyatakan terdapat signifikansi perbedaan terhadap respon tersebut dari responden dengan berbagai macam pekerjaan.

\section{Pembahasan}

BRT Purwokerto-Purbalingga adalah salah satu moda transportasi baru di bawah pengawasan Departemen Perhubungan Jawa Tengah. BRT ini mempunyai satu manajemen dengan BRT yang ada di Semarang dengan tagline BRT Trans Jateng. BRT ini sudah beroperasi dua tahun lebih dan keberadaanya diharapkan menjadikan kemanfaatan bagi masyarakat Purwokerto, Purbalingga, dan sekitarnya. Pada praktiknya, BRT juga mempunyai keunggulan lain, yaitu 
terkait harga tiket yang sangat terjangkau dan aman (Venter, Hidalgo, \& Pineda, 2013). Keunggulan lainnya adalah membantu mengurangi permasalahan kesehatan akibat polusi udara (Chengula, 2017). Pada prinsipnya, pada pengoperasian BRT terdapat berbagai kebutuhan dasar yang harus dipenuhi seperti halte atau stasiun, kendaraan, system tiket, identitas citra BRT pelayanan (Agarwal, Anupama, \& Singh, 2010) \& rencana pengembangan pengoperasian (Chanda, Sai, \& Goutham, 2014).

Selain keunggulan tersebut, BRT juga dapat dijadikan icon suatu daerah dengan konsep transportasi yang terintegrasi atau saling terkait dengan moda transportasi lainnya. Sebagai icon, BRT harus memiliki keunikan, terutama untuk membentuk sebuah branding trasportasi kota. Icon ini memiliki bebeberapa elemen seperti tipografi, simbolisme, ilustrasi, dan fotografi. Elemen tersebut digabungkan menjadi satu dengan kaidah desain komunikasi visual sehingga menghasilkan produk komunikasi visual sebagaimana yang terdapat pada badan BRT ini.

Persepsi masyarakat terhadap media promosi yang digunakan juga harus diperhatikan elemen-elemen desainnya supaya dapat mudah dikenal masyarakat hanya dengan melihat media promosinya dan sama antar satu orang yang melihat dengan lainnya. Sebab pada dasarnya persepsi dalam desain itu harus sama antara satu orang dengan lainnya. Hal tersebut sudah diterapkan dalam promosi BRT Purwokerto- Purbalingga. Apalagi bila melihat tujuannya adalah membentuk sebuah icon transportasi daerah jelas itu harus dipilih yang mudah diingat dan diucapkan oleh masyarakat saat melihatnya pertama kali.

Icon juga dapat dijadikan media promosi. Hal inilah yang digunakan sebagai dasar penilaian oleh responden terhadap komunikasi visual pada badan BRT sebagai media promosi. Dengan adanya media promosi akan semakin banyak masyarakat Purwokerto-Purbalingga yang mengenal BRT. Berdasarkan perhitungan skala likert, hanya respon pada BRT memiliki elemen komunikasi visual memiliki persentase tertinggi. Hal ini mengindikasikan mayoritas responden sangat setuju bahwa BRT menggunakan media promosi komunikasi visual. Komunikasi visual ini digunakan BRT untuk mempromosikan tempat-tempat wisata di Purwokerto dan Purbalingga. BRT telah menciptakan branding dirinya dengan sebuah komunikasi visual yang mampu memberikan perbedaan dengan angkutan umum lainnya. Sehingga terbukti BRT yang memiliki visualisasi akan lebih menarik masyarakat sehingga masyarakat menjadi lebih tertarik untuk menggunakan BRT tersebut.

Beberapa persepsi transportasi terutama BRT juga telah banyak digunakan. Seperti perbaikan sistem parkir untuk mengurai kemacetan. Solusi yang ditawarkan adalah pelebaran jalan, jalur khusus BRT dan pengadaan lahan parkir (Nizam, Astuti, \& Manan, 2017). Lebih lanjut lagi, rekomendasi terkait pengoperasian BRT dapat berupa penambahan jumlah armada tersebut, waktu tunggu yang lebih cepat, lalu fasilitas halte yang harus ditingkatkan, dan penambahan jalur khusus, serta pengurangan penumpukan penumpang di halte perlu diperhatikan juga demi menjaga kenyamanan konsumen yang menggunakan BRT (Mardalisa, Hermon, \& Despica, 2015). Pada konteks ini, rekomendasi ditekankan pada persepsi komunikasi visual badan BRT. Berdasarkan persentase, ditunjukkan hasil bahwa mayoritas masyarakat menyetujui respon tersebut untuk diberlakukannya komunikasi visual di badan BRT. Pada respon dengan persentase di bawah 70\%, terdapat beberapa indikasi bahwa masyarakat masih menganggap terdapat beberapa ketidakpuasan terkait 


\section{Fauzan Romadlon' Pungky Febi Arifianto ${ }^{2}$ Nofrizaldi $^{3}$}

Persepsi Komunikasi Visual Terhadap Media Promosi BRT (Bus Rapid Transit) Trans Jateng Koridor Purwokerto-Purbalingga desain komunikasi visual BRT sebagai media promosi. Hasil tersebut merasa beberapa media promosi yang digunakan kurang menggambarkan persepsi masyarakat dalam melihat visualisasi di BRT yang diharapkan dan dirasa belum sesuai apabila diterapkan untuk media promosi BRT. Seperti belum adanya cukup pengaruh terhadap banyaknya penerapan elemen desain pada media promosi yang digunakan di badan BRT yang dirasa kurang menarik konsumen sebagai target market BRT tersebut. Selain itu, beberapa masyarakat menginginkan promosi melalui desain komunikasi visual BRT yang eye catching dan kekinian dan tulisan promosi pada badan BRT dibuat agar lebih jelas, lebih besar, dan lebih menarik.

Pada perhitungan statistika, terdapat beberapa perbedaan signifikan terhadap respon masyarakat dengan demografinya. Perbedaan signifikan ini ditunjukkan pada semua respon kecuali respon terhadap elemen komunikasi visual (A1). Mayoritas perbedaan yang signifikan respon tersebut meliputi jenis kelamin dan tipe pekerjaan masyarakat. Faktanya, laki-laki dan perempuan mempunyai perspektif yang berbeda terkait desain komunikasi visual yang diterapkan di badan BRT. Ditambah lagi dengan latar belakang profesi yang berbeda. Perbedaan ini dapat disebabkan oleh beberapa faktor seperti tingkat kesukaan pada warna, pengalaman komunikasi visual, dan promosi yang diharapkan. Tingkat kesukaan warna antara laki-laki dan perempuan biasanya berbeda, hal inilah yang menjadikan perbedaan dalam memilih komponen-komponen visual. Selain itu, pengalaman komunikasi visual juga memiliki dampak yang berarti karena desain itu juga dapat mempengaruhi psikologi seseorang yang melihatnya. Pengalaman komunikasi visual ini dapat terjadi bila masyarakat pernah melihat dan membandingkan badan BRT Purwokerto-Purbalingga dengan BRT lain di Indonesia. Lebih lanjut lagi, promosi yang diharapkan oleh masyarakat umumnya semakin beragam. Promosi ini tidak hanya sebatas promosi wisata, dimungkinkan juga promosi kuliner, promosi batik, dan ajakan menggunakan transportasi umum hingga kampanye pencegahan perilaku korupsi.

\section{Kesimpulan}

Penelitian ini berfokus terhadap persepsi masyarakat terhadap komunikasi visual BRT sebagai media promosi. Persepsi pengguna dijabarkan dalam beberapa pertanyaan yang dapat menggambarkan pengalaman masyarakat terhadap BRT baik pada masyarakat yang telah menggunakan maupun yang belum.

Berdasar kaidah visual, persepsi ini didasari pada elemen-elemen yang terdiri dari tipografi, simbolisme, ilustrasi, dan fotografi Elemen tersebut digabungkan menjadi satu sehingga menjadi icon dalam livery BRT Purwokerto-Purbalingga.

Persepsi yang beragam secara statistik didasari oleh faktor demografis terutama jenis kelamin dan tipe pekerjaan. Sebab sebuah promosi desain pasti sudah memiliki target pasarnya atau sasarannya masing masing sesuai dengan yang ditujukan seorang desainer. Hal tersebut sudah diterapkan di promosi BRT yaitu untuk masyarakat Purwokerto-Purbalingga dan sekitarnya.

Studi ini masih memiliki beberapa kekurangan antara lain sebaran demografis dan kajian persepsi yang masih belum komprehensif. Harapan ke depan dilakukan kajian yang lebih mendalam terkait desain visual BRT yang sesuai dengan permintaan pasar sehingga memudahkan dalam melakukan promosi wisata dan promosi program pemerintah yang lain. Desain visual tersebut dapat berupa penonjolan kekhasan daerah sehingga BRT ini mampu menjadi icon kebanggaan dari sisi transportasi. 


\section{Referensi}

Afolabi, O. U. (2016). Commuters Perception And Preferences On The Bus Rapid Transit In Lagos State. JORIND, 14(2), 34-41.

Agarwal, Anupama, S., \& Singh. (2010). An overview on Bus Rapid Transit System. Journal of Engineering Research and Studies, 1(2), 195-205.

Akbar, S. M. (2018). Pengalaman Naik BRT Trans Jateng Purbalingga - Purwokerto. Retrieved April 14, 2020, from matamatanews website: https:// www.matamatanews.com/brt-transjateng-purwokerto--purbalingga-bikin-penasaran-masyarakat

Cao, J., Cao, X., Zhang, C., \& Huang, X. (2015). The gaps in satisfaction with transit services among BRT, metro, and bus riders: Evidence from Guangzhou. Journal of Transport and Land Use, 97-109. https://doi.org/10.5198/ jtlu.2015.592

Chanda, B. K., Sai, M., \& Goutham, S. (2014). Introduction to corridor selection \& assessment for Bus Rapid Transit System ( BRTS ) in Hyderabad. American Journal of Engineering Research ( AJER ), 03(06), 242-246. https://doi.org/10.1016/j. tranpol.2016.12.002

Chengula, D. (2017). Assessment of the Effectiveness of Dar Es Salaam Bus Rapid Transit ( DBRT ) System in Tanzania. International Journal of Sciences, $4531,10-30$

Dishubjabar. (2015). Mengenal Bus Rapid Transit (BRT). Retrieved August 13, 2018, from dishubjabar website: http://dishub.jabarprov.go.id/artikel/view/566.html
Fiadcara, J. (2004). Communication Design: Principles, Method, And Practice,. New York: Allwort Press.

Kasih, L. (2018). 8 Unit Bus Trans Jateng Beroperasi di Banyumas. Retrieved April 14, 2020, from joss.co.id website: https://joss.co.id/2018/08/8unit-bus-trans-jateng-beroperasi-dibanyumas/

Kotler, P., \& Keller, K. L. (2012). Marketing Management. Retrieved from https://books.google.co.id/ books?id=eMZRYgEACAAJ

Mardalisa, Hermon, D., \& Despica, R. (2015). Preferensi Masyarakat Terhadap Efektifitas Trans Padang di Kota Padang. Jurnal Ilmiah Mahasiswa STKIP PGRI Sumbar.

Meutia, W., Wibowo, S. S., \& Weningtyas, W. (2015). Kajian Persepsi Penerimaan Masyarakat Terhadap Kebijakan Transportasi untuk Kawasan Rencana Ecovillage Tamansari Di Kota Bandung. The 18th FSTPT International Symposium Unila Bandar Lampung Unila Bandar Lampung.

Nizam, M. T., Astuti, P., \& Manan, M. (2017). Preferensi Masyarakat Tentang Alternatif Pemecahan Masalah Transportasi Di Jalan Riau Kota Pekanbaru. Jurnal Teknik Sipil Unaya, 2(1), 1-12.

Nurhayati, D. (2018). Fenomena Transjakarta

Sebagai Media Beriklan Di Jakarta. Jurnal ATRAT, 6(1), 91-100.

Nurchotimah, S. (2018). Persepsi Masyarakat Tentang Kebijakan Transportasi Online Di Terminal Purabaya Sidoarjo.

Ridlo, M. (2018). Ayo, Cek Jadwal dan Rute BRT Gratis Purwokerto-Purbalingga. Retrieved August 13, 2018, from liputan6.com website: 
Fauzan Romadlon'

Pungky Febi Arifianto ${ }^{2}$

Nofrizaldi $^{3}$

https://www.liputan6.com/regional/read/3616543/ayo-cek-jadwal-dan-rute-brt-gratis-purwokerto-purbalingga

Tinarbuko, S., \& Piliang, Y. A. (2008). Semiotika komunikasi visual. Retrieved from https://books.google.co.id/ books?id=jHqvAQAACAAJ

Venter, C., Hidalgo, D., \& Pineda, A. F. V. (2013). Assessing the equity impacts of Bus Rapid Transit : emerging frameworks. 13th World Conference on Transportation Research, 1-18.
Persepsi Komunikasi Visual Terhadap Media Promosi BRT (Bus Rapid Transit) Trans Jateng Koridor Purwokerto-Purbalingga 